\title{
Alterações morfológicas das fibras tipos I e II do músculo estriado uretral de ratas prenhes diabéticas
}

\section{Gabriela Marini}

Dissertação apresentada ao Programa de PósGraduação em Ginecologia, Obstetrícia e Mastologia, da Faculdade de Medicina de Botucatu

- UNESP, para obtenção do título de Mestre.

Orientadora: Profa. Titular Marilza Vieira Cunha Rudge

Co-orientadora: Profa. Dra. Angélica Mércia Pascon Barbosa

Co-orientadora: Profa. Dra. Selma Maria Michelin Matheus 


\title{
FICHA CATALOGRÁFICA ELABORADA PELA SEÇÃO TÉCNICA DE AQUISIÇÃO E TRATAMENTO DA INFORMAÇÃO DIVISÃO TÉCNICA DE BIBLIOTECA E DOCUMENTAÇÃO - CAMPUS DE BOTUCATU - UNESP BIBLIOTECÁRIA RESPONSÁVEL: Selma Maria de Jesus
}

\author{
Marini, Gabriela. \\ Alterações morfológicas das fibras tipos I e II do músculo estriado uretral de \\ ratas prenhes diabéticas / Gabriela Marini. - Botucatu: [s.n.], 2010. \\ Dissertação (mestrado) - Faculdade de Medicina de Botucatu, Universidade \\ Estadual Paulista, 2010. \\ Orientador: Marilza Vieira Cunha Rudge \\ Co-orientadora: Angélica Mércia Pascon Barbosa e Selma Maria Michelin \\ Matheus \\ Assunto CAPES: 40101150 \\ 1. Diabetes na gravidez 2. Uretra - Morfologia
}

Palavras-chave: Diabete; Fibra muscular estriada; Prenhez; Uretra 


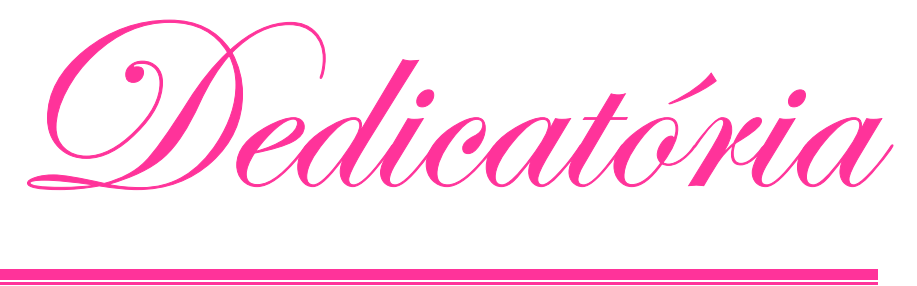


A Deus e Nosso Senhor Jesus Cristo, pelo dom da vida, por ter me guiado sempre por bons caminhos, me proteger dos iníquos, pela revelação do seu amor e pela intercessão do Divino Espírito Santo;

Ao meu pai, José Roberto, que cedo se foi me deixando ainda pequenina, mas de quem guardo poucas, mas maravilhosas lembranças, de carinho, afeto e amor;

À minha amada mãe, Maria Helena, que não tenho palavras para descrever tudo que sinto. Mulher perfeita, forte, corajosa, guerreira, que me ensinou a ter caráter, respeito ao próximo e não desistir nunca. Abriu mão de sua vida e de suas vontades para criar com muito esforço suas filhas, e aqui estamos nós! Quando Deus a levou, perdi meu rumo, meu chão, minha razão de viver, mas com o tempo, percebi que ela apenas foi antes e que está comigo todos os dias da minha vida, me guiando e protegendo. Ainda sinto o calor de sua pele, seu cheiro, sua mão dada com a minha e seu abraço, como se ainda dormisse ao meu lado todos os dias;

À minha irmã, Carol, a quem devo tudo e sem ela com certeza eu não teria conseguido. Ela foi meu chão, minha razão para continuar, quando tudo parecia perdido. Sempre esteve ao meu lado nas horas mais difíceis e sempre fez tudo para tornar minha vida mais alegre e amenizar minhas dores. É hoje sem dúvida, minha segunda Mãe. Como é doloroso tornar-se adulto!;

Ao meu cunhado Celso, que sempre me apoiou, e que me acolheu em sua vida e em sua casa, com muito carinho e dedicação, como se eu fosse uma irmã ou mesmo uma filha, não medindo esforços para me ajudar; 
Ao meu namorado Fabrício, por ter aparecido em minha vida, ganhado meu coração e minha confiança e estar me ajudando a ser uma pessoa melhor; e por todo acolhimento que recebi da sua família e seus amigos;

Por todos meus familiares, tios, primos e avós; a minha querida avó Isaura por ter me ensinado a amar não apenas as pessoas fáceis e que falam o que queremos ouvir; em especial aos meus primos Mateus, Ana Paula, Marcos Paulo, Larita e Rogério e para a luz dos meus olhos, meu pequeno afilhado Pedro;

Ao Celso e Ana, por terem me acolhido de forma tão carinhosa em sua casa, todas as vezes que precisei;

Às minhas amigas Betina, Melina, Andressa, Luana, Ana Renata, Liamara, Samara, Viviane, Luciara, Fernanda, Mariza, D. Maria e Joaquim;

Às minhas amigas de casa, Flávia, Taísa, Michele e Andréia, por tranquila e agradável convivência;

À Frida e Sandy, por me ensinarem o amor gratuito e incondicional, e serem o elo entre meu passado e o presente. Perdoer me pela ausência! 


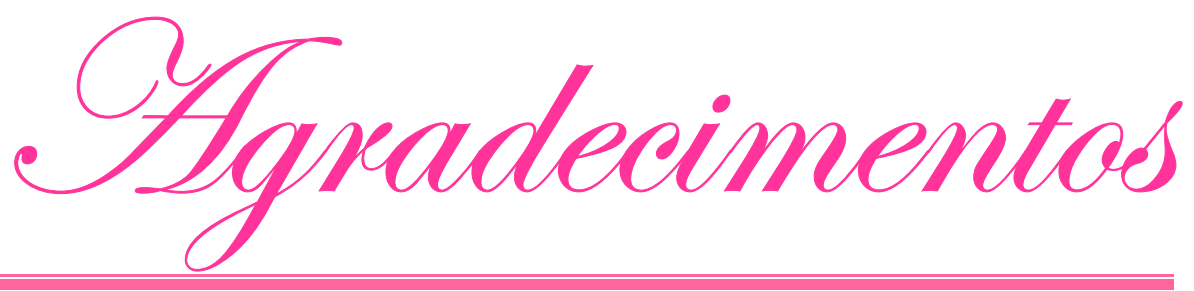


À Profa. Dra. Marilza V.C. Rudge, por todos seus ensinamentos profissionais e pessoais, por sua paciência, dedicação, determinação e confiança. Por ter me acolhido em sua casa e me deixar participar um pouco da sua vida. Exemplo de mãe, mulher, esposa e profissional. Também agradeço o carinho do seu esposo Dr. Aristides e de sua filha Dra.Cibele.

À Profa. Dra. Angélica M.P. Barbosa, pela dedicação, paciência, grandes ensinamentos de vida, e por sempre ter acreditado na minha capacidade. Com certeza, sem ela eu não estaria aqui hoje. É como todos diziam e por todo meu carinho e admiração, minha "mãezona".

À Profa. Dra. Selma M.M. Matheus, que Deus colocou no meu caminho. Sempre esteve disposta a me ajudar em todas as horas, foi o meu socorro nos momentos difíceis, e muito além do ensino acadêmico, me ensinou que para ajudar o próximo simplesmente não precisamos ganhar nada em troca;

À Profa. Dra. Débora C. Damasceno, que desde o início teve muita paciência diante da minha imaturidade, e hoje, tenho muito carinho, admiração e respeito. Também, está sendo responsável por meu grande crescimento profissional, pessoal e religioso. Agradeço também seu marido Carlos e sua filha Dani, por momentos agradáveis de convivência;

Ao Prof. Dr. Jair de Campos Soares, que foi o ponto de partida do meu projeto, acompanhou todo meu crescimento e foi crucial para o término deste trabalho; 
Ao Prof. Dr. Manoel J.B.C. Girão, que gentilmente abriu as portas da Universidade Federal de São Paulo e sugeriu a inclusão do gruł diabético no projeto inicial;

Ao Prof. Dr. Rodrigo A. Castro, que sem dúvida Deus colocou no meu caminho no momento certo para o andamento do meu projeto; possibilitou a realização da imunoistoquímica; confiou em meu trabalho; sua perseverança, bondade, sabedoria e coragem, sem dúvida, fizeram que tudo acontecesse para que conseguíssemos vencer;

Ao Prof. Dr. Jorge M. Haddad, que também confiou em meu trabalho e teve muita paciência, bom censo, carinho e atenção;

À Profa. Dra. Suely K.N. Marie, por todos seus ensinamentos científicos e profissionais, e por ter colocado a disposição seu laboratório;

Ao Prof. Dr. Adriano Dias e à Profa. Dra. Iracema de Mattos P.Calderon, por todos seus ensinamentos e atenção;

Aos colegas e amigos do Laboratório de Pesquisa Experimental de Ginecologia e Obstetrícia que foram indispensáveis para esta conquista: Aline Bueno, Aline de Oliveira Netto, Ana Maria C. Ruocco, Bruna Dallaqua, Carolina Amaral de Alcântara, Edlaine Cristina de Lego, Felipe Hiroshi Saito, Glilciane Morceli, Isabela Lovizutto Iessi, Jusciele Brogin Moreli, Lessandra de Rosa Santos, Marcelo B. Casarri, Marcos José T. Caetano, Rafael Bottaro Gelaleti, Silvana B. Corvino, Vânia B. Magalhães e Yuri Karen Sinzato; à Kristin Nicole Taylor pela disponibilidade e eficiência na correção do texto;

À aluna Carolina Cunha da UNIFESP, que colaborou com este projeto e que considero uma grande amiga; 
A todos do Laboratório da USP (LIM 15), por grandes ensinamentos e dedicação em me ajudar; Ao Marcos, p disponibilidade, paciência e conselhos. Obrigada pela imunoistoquímica;

Aos funcionários da Seção de Pós-Graduação, Janete, Lilian, Regina e Nathanael pela simpatia e solicitude;

A todos os funcionários do Departamento de Ginecologia e Obstetrícia, em especial á Ana Claudia Garcia Mira pela paciência e atenção;

A todos os funcionários e amigos da Experimental em especial ao Carlos R.Gonçalves Lima;

Aos docentes e funcionários do Grupo de Apoio à Pesquisa (GAP);

Aos animais, que apesar de ter me acostumado, prometi que jamais perderia meus sentimentos, afinal, são criaturas divinas que estão a serviço da ciência;

À Fundação de Amparo à Pesquisa do Estado de São Paulo (FAPESP), pela concessão da bolsa (Processo n’. 2008/00989-4).

A todos que contribuíram de alguma forma para a realização deste trabalho. 


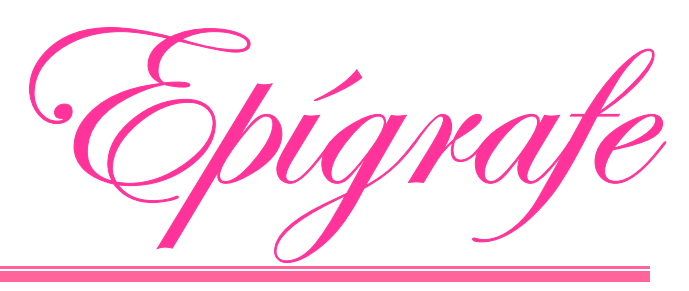




\section{"Perder alguém querido,}

Palavras não explicam a morte de alguém querido. Sabem disso o pai, a mãe, os filhos, os irmãos, o marido e a mulher, e os amigos de verdade.

Quando o outro morre, parte do mistério da vida vai com ele. A parte que fica torna-se mais intrigante. Descobrimos a relação profunda entre a vida e a morte, quando alguém que era a razão de nossa vida vai-se embora.

Para onde? Para quem? Está me ouvindo? A gente vai se ver de novo? Como será nosso reencontro? Acabou-se para sempre, ou ela apenas foi antes? Por que agora? Por que deste jeito? As perguntas insistem em aparecer e as respostas não parecem claras. Dói, dói, dói.

Um dia nos veremos de novo. Enquanto este dia não vem, quem eu amo e se foi. Para ela, a vida tem agora, outra dimensão. Alcançou o infinito.

Por enquanto fica apenas o mistério. Alguém que não sabemos por que entrou tão cheio em nossas vidas, fechou os olhos e foi-se embora. Quem ama de verdade não crê que se acabou. A vida é uma só. Começa aqui no tempo e continua depois, na ausência de tempo e limite.

Alguém a quem amamos se tornou eterno. E essa pessoa já sabe quem e como Deus é. $E$ também sabe o porquê de sua partida. Se ela está no céu então alguém, além de Deus e de Jesus, se importa comigo. Definitivamente, não estamos sozinhos por mais que doa a solidão de havê-lo perdido.

Mas é apenas por pouco tempo

Quem amou aqui, sem dúvida, se reencontra no infinito.

Ninguém ama aquilo que não conhece

Mas ninguém esquece daquilo que ama.

Quando tudo falha é tempo de confiar!" 


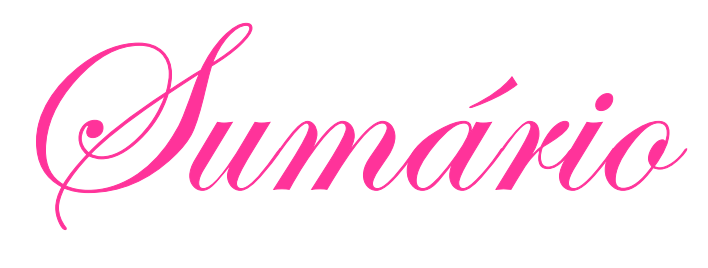


Capítulo 1- Diabetes in pregnancy and urinary incontinence:

little acknowledged association

Capítulo 2- Morphological changes in muscle mass and in fastto-slow fiber profile in urethral striated muscle fibers of diabetic pregnant rats. .28

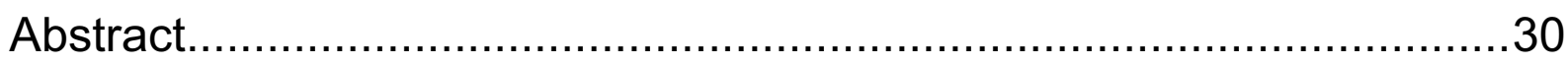

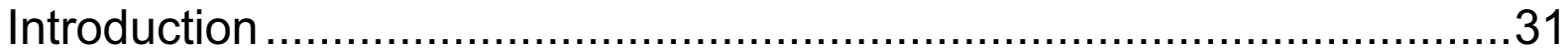

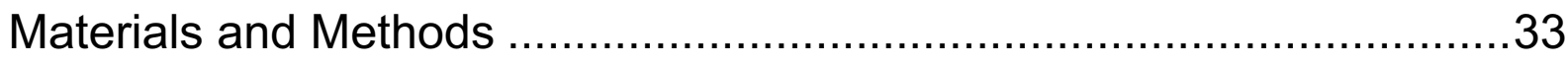

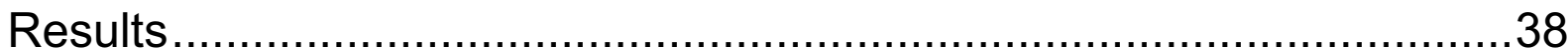

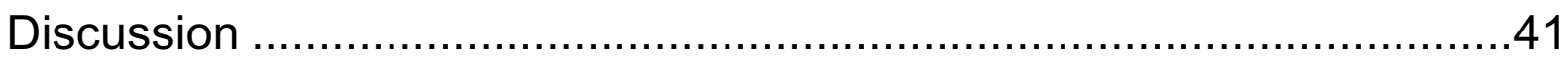

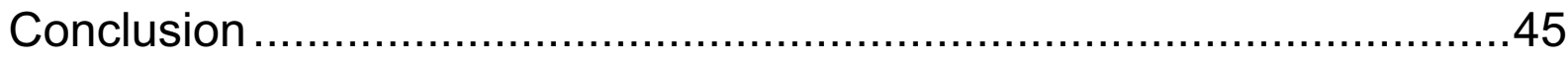

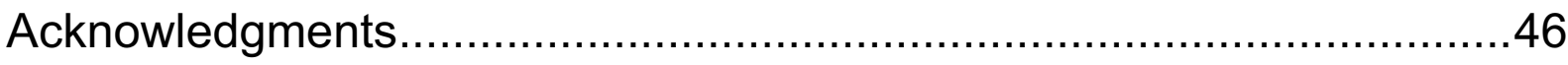

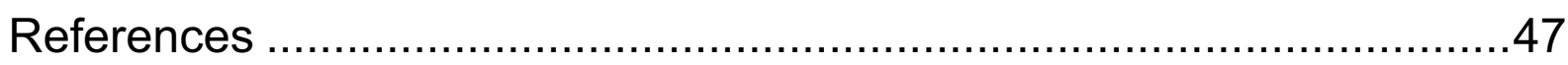

Capítulo 3- Alterações morfológicas das fibras tipos I e II do músculo estriado uretral de ratas prenhes diabéticas

ANEXOS

ANEXO 1- Aprovação do Comitê de Ética

ANEXO 2- Alteração no Título

ANEXO 3- Ofício do envio para publicação do Capítulo 1 63 
Alegrai-vos sempre no Senhor. Seja conhecida de todos os homens a vossa bondade. Não vos inquieteis com nada! Em todas as circunstâncias apresentai a Deus vossas preocupações, mediante a oração, as súplicas e a ação de graças. E a paz de Deus que excede toda a inteligência, haverá de guardar vossos corações e vossos pensamentos, em Cristo Jesus.

Filipenses 4:4

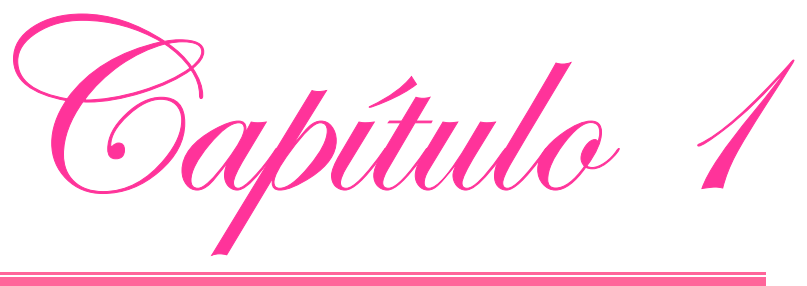




\section{Diabetes in pregnancy and urinary \\ incontinence: a little acknowledged association}

Gabriela Marini ${ }^{1}$, Angélica Mércia Pascon Barbosa ${ }^{1}$, Débora Cristina Damasceno ${ }^{1}$, Rodrigo de Aquino Castro ${ }^{2}$, Selma Maria Michelin Matheus ${ }^{3}$, Marilza Vieira Cunha Rudge ${ }^{1}$ *

1 Experimental Research Laboratory, Department of Gynecology and Obstetrics - Botucatu Medical School, UNESP - Univ Estadual Paulista, São Paulo, Brazil.

${ }^{2}$ Department of Gynecology, São Paulo Federal University (UNIFESP), São Paulo, Brazil.

${ }^{3}$ Department of Anatomy, Botucatu Biosciences Institute, UNESP - Univ Estadual Paulista, São Paulo, Brazil.

* Correspondence: Marilza Vieira Cunha Rudge. Experimental Research Laboratory, Department of Gynecology and Obstetrics, Botucatu Medical School, UNESP -Univ Estadual Paulista - CEP 18618-000 - Botucatu, São Paulo, Brazil

Este capítulo foi redigido de acordo com as normas de publicação da revista Diabetology \& Metabolic Syndrome, para a qual foi submetido. 


\section{Abstract}

Urinary incontinence (UI) in women is defined as any involuntary urine loss. It is a frequent condition of high economic cost to the government that also results in women's physical, psychological and social damage and impaired quality of life. Various risk factors are involved in UI development; however, association with Diabetes mellitus (DM) is of great interest at present. DM affects multiple organ systems, including the urinary system in approximately $52 \%$ of diabetic patients and in those showing only hyperglycemia; however, the association between gestational DM and UI has not been fully explained. Health care professionals must be attentive to this new parameter and attempt to analyze it in more detail so that prophylactic and therapeutic measures can be established. It is necessary to delineate the chronology of the relationship between gestational Diabetes mellitus and vesical complications, the relationship between controlled diabetes and the incidence of incontinence as well as effective treatment modalities for diabetic patients with symptoms in the lower urinary tract.

Key words: diabetes, pregnancy, urinary incontinence 


\section{Introduction}

Urinary incontinence (UI) in women is defined as any involuntary urine loss [1]. It is a frequent condition of high economic cost to the government that also results in women's physical, psychological and social damage and impaired quality of life [2, 3].

The world epidemic of obesity and type-2 diabetes has significant implication in the occurrence of UI in women [4]. However, the mechanisms by which diabetes contributes to the UI development and severity are not well defined.

Diabetes is related to muscular strength and physical function impairment, and it may reflect the connection between the muscle's metabolic and mechanic functions. There is a temporal relation between Diabetes mellitus (DM) diagnosis and the subsequent development of muscular weakness associated with complications such as diabetic amyotrophy. Hyperglycemia may affect the contractile function and strength generation in the muscle [5].

In 2006, the association of Gestational Diabetes mellitus (GDM) with UI increases and muscular dysfunction on the pelvic floor two years after gestation became clear. Pregnant women with GDM showed $50.8 \%$ of UI in pregnancy as compared to $31.6 \%$ in non-diabetic individuals $(p<0.05)$. The presence of GDM increased not only IU occurrence two years after childbirth, but it was also associated with $\mathrm{UI}$ in pregnancy [6]. Such association is little acknowledged in the literature because there are still other concerns to be solved regarding the diabetes-pregnancy binomial. 


\section{Historical development of GDM}

The $20^{\text {th }}$ century witnessed the change in pregnant women's follow-up. At the beginning of that century diabetic women died; they later became infertile and rarely had successful at-term pregnancies. The advent of insulin in 1922 abolished maternal death and, over the past century, all efforts were made to improve perinatal results.

The first concern was the moment of childbirth and, later, the perinatal complications resulting from intrauterine hyperglycemia, such a fetal macrosomy [7]. White's clinical classification [8] established a direct relation between the severity of maternal clinical conditions and the moment of delivery, and it was fundamental in reducing perinatal death. As a result, there was significant increase in cesarean section rates in the population [9].

Despite all the present efforts, perinatal death rates, congenital malformation cases excluded, is slightly higher than those found for the non-diabetic population [10]. At the moment, the literature attempts to solve the problem of fetal malformations and of the large obesity and diabetes epidemic around the world which has resulted in the increase of pregnancies complicated by diabetes. It can be imagined that, in this century, the concern regarding this binomial will be focused on preventing the occurrence of fetal malformation, finding more refined and earlier diagnostic methods as well as on furthering the knowledge on more subtle GDM outcomes in the maternal organism.

Although diabetes is the most common medical complication in pregnancy, the association between GDM and $\mathrm{UI}$ is not reported in obstetric textbooks. The recommended classification is based on the quality of maternal metabolic control and emphasizes that the compromising of target organs, such as the kidneys, eyes and 
heart, has a significant effect on pregnancy outcomes. That classification does not make any reference to the compromising of the lower urinary tract in diabetic pregnant women or to whether this may be an aggravating factor in maternal and perinatal prognosis.

\section{Diabetes in pregnancy}

DM is one of the most common endocrine disorders, and it affects approximately $7 \%$ of the world population and $50 \%$ of diabetic individuals are not aware of their diagnosis [11]. Diabetic pregnant women can be separated into two large groups: those who already had the diabetes diagnosis prior to pregnancy (clinical diabetic women) and those who are diagnosed during their pregnancies (gestational diabetic women). It is estimated that $10 \%$ of them have clinical diabetes and $90 \%$ gestational diabetes [7].

The total number of individuals with diabetes is expected to increase from 171 million in 2000 to 366 million in 2030. Its expansion follows population growth and ageing, urbanization as well as obesity and sedentariness increase [12]. Such population growth in the diabetic population worldwide will not only increase diabetes occurrence in pregnancy, but it will also change the proportion of clinical and gestational diabetic women.

\section{Diabetes mellitus and urinary incontinence}

DM affects multiple organ systems, including the urinary system in approximately $52 \%$ of diabetic patients and in those showing only hyperglycemia. Various epidemiological studies have observed increased risk (50 to $200 \%$ more commonly) for UI in women with type-2 as compared to those with normal glucose 
levels [13]. The risk factors involved in UI development are many; however, the association with diabetes is of great interest at present.

Diabetes, waist circumference, parity and low social support are associated with increased prevalence of stress urinary incontinence (SUI) whereas a high body mass index and impaired health are associated with UI incidence [14].

$\mathrm{UI}$ is also common among women with DM 1, and risk factors including old age, weight increase and previous urinary infection are important. Weight reduction and infection treatment can prevent UI or reduce its severity [15].

UI prevalence in a group of 1,585 women older than 20 years was of $49.5 \%$. UI was significantly associated with older age, poor education, recurrent urinary-tract infection, Diabetes mellitus, history of nocturnal enuresis in childhood, diuretic medication and BMI [3]. It was also characterized as more severe in women with DM [16].

Urge UI was more prevalent in non-diabetic women whereas mixed $\mathrm{UI}$ and SUI were more prevalent in diabetic women. Of the diabetic women, $41 \%$ reported UI, and DM was an independent determinant factor of UI [17].

UI was reported by $65 \%$ of the women with DM 1 . Of these, $40 \%$ were very annoyed by their incontinence, and $9 \%$ believed that it did not affect their daily activities. The prevalence of weekly urge incontinence was twofold in women with DM 1 as compared to that of women without diabetes. Additionally, UI prevalence was higher than that of neuropathy, retinopathy and nephropathy. These findings point out the importance of tracking urinary incontinence among women with DM 1 [18].

Brown et al., [13] found high UI incidence in women with DM 2 or with hyperglycemia when compared to women with normal glucose levels. 
This literature review clearly shows that the association between diabetes and UI has been acknowledged. Nevertheless, the clinical meaning of UI, its short- and long-term outcomes and the need or not for treatment and prophylaxis has not been established.

\section{Diabetes in pregnancy and UI}

The association between GDM and increased UI prevalence and muscular dysfunction of the pelvic floor has been clearly shown by Barbosa,[6] who concluded that the prevalence of gestational UI two years after childbirth was significantly higher in women with GDM than among normoglycemic pregnant women. Multivariate analysis has shown GDM to be an independent risk factor for the occurrence of gestational UI.

Kim et al., [19] also observed that $49 \%$ of the women with GDM reported frequent incontinence during pregnancy, and $28 \%$ reported that such $U I$ affected their daily activities. They concluded that SUI is common among women with GDM, and it does not seem to be associated with physical activity levels or body mass index.

DM was also associated with vesical dysfunction, such as sensory abnormalities that result in vesical sensitivity impairment, increased complacency and increased residual volume; UI and sexual dysfunction in women, such as inhibited desire, pain during intercourse and inadequate lubrication [20].

These reports on the association of GDM with UI are relatively recent in the literature, little acknowledged and little valued by medical professionals. There are no reports in the literature on the clinical maternal meaning of such UI in pregnancy and nor on the possible correlations between its occurrence and maternal and perinatal outcomes. 


\section{Experimental models}

Experimental severe diabetes induction is well established, including in pregnancy [21], and many studies have confirmed its effects on the lower urinary tract of animal models.

Diabetic rats with higher glycemia than $300 \mathrm{mg} / \mathrm{dL}$ (6-8 weeks) showed significantly increased vesical capacity and increased intercontraction intervals, extensive damage in the external urethral sphincter (EUE), atrophy in the urethral vaginal septum and increased collagen deposition between the striated muscles. UI was more severe, and the recovery of the damages generated by vaginal distention was delayed in the diabetic group. The authors suggest that diabete is related to the accumulation of free radicals and ischemia, which can interact or be independent factors to generate dysfunctions in the lower urinary tract [22].

Diabetes caused effects on the bladder and urethra of rats 06 weeks after induction, such as decreased vesical sensitivity, increased vesical capacity, increased residual volume and detrusor contractility impairment. After 20 weeks, an atrophy was found in the EUE, which was related to the polyneuropathy found in DM [23]. Significant decrease in the skeletal muscle mass of STZ-induced rats (example of diabetic myopathy) was also observed in another study [24].

Diabetes is also associated with a reduction in the capillarization of the skeletal muscle and a deregulation in the angiogenesis route in the quadriceps muscle of rats with severe diabetes ( 3 to 5 weeks) [25].

However, in more recent studies, pregnancy and caesarean sections did not induce alterations in the number of collagen, muscle, elastic and nerve fibers. But vaginal birth and simulation of delivery trauma reduced muscle and nerve fibers and increased collagen and elastic fibers [26]. 
Studies on diabetic pregnant rats have not been found.

\section{Conclusions}

Despite the high UI prevalence in diabetic pregnant and non-pregnant women, many of them do not report their incontinence to clinicians, and those who do are given the simplest explanation attributed to polyuria caused by DM itself. Such knowledge has been recently developed in this century, and the association between GDM and UI and its relevance has not yet been established. Science and medicine move as follows: firstly, a phenomenon is observed. Later, its actual importance is analyzed and then the need for treatment and prophylaxis is evaluated. The phenomenon is confirmed. Its importance must be studied in experimental models and in clinical observations during pregnancy by evaluating its maternal and perinatal outcomes. Health care professionals must be attentive to this new parameter and seek to analyze it in more detail so that prophylactic and therapeutic measures can be established.

It is necessary to delineate the chronology of the relationship between GDM and vesical complications, the relationship between controlled diabetes and the incidence of incontinence as well as effective treatment modalities for diabetic patients with symptoms in the lower urinary tract. 


\section{List of abbreviations}

UI (urinary incontinence), DM (Diabetes mellitus), GDM (Gestational Diabetes mellitus), SUI (stress urinary incontinence), EUE (external urethral sphincter).

\section{Competing interests}

The authors declare that no competing interests exist.

\section{Authors' contributions}

All authors have participated in the manuscript's design and drafting. All authors have participated in the study's review of the data shown and they have read and approved of the final manuscript version.

\section{Acknowledgements}

Financial support was provided by a fellowship from Fundação de Amparo à Pesquisa do Estado de São Paulo (FAPESP), at Gabriela Marini (Grant/Process Number 2008/00989-4). This study constituted part of the MSc Thesis presented to UNESP, in 2010, by Gabriela Marini. 


\section{References}

1. Abrams P, Cardozo L, Fall M, Griffiths D, Rosier P, Ulmsten U, et al. The standardization of terminology in lower urinary tract function: report from the standardization sub-committee of the International Continence Society. Urology. 2003 Jan, 61(1):37-49.

2. Subak L, Brown J, Kraus R, Brubaker L, Lin F, Richter HE, et al. The "costs" of urinary incontinence for womem. Obstet Gynecol. 2006, 107(4):908-16.

3. Tozun M, Ayranci U, Unsal A. Prevalence of Urinary Incontinence among Women and Its Impact on Quality of Life in a Semirural Area of Western Turkey. Gynecologic an Obstetric Investigation. 2009, 67:241-9.

4. Holroyd-Leduc J, Straus S. Manegement of urinary incontinence in women: scientific review. JAMA. 2004, 291:986-95.

5. Sayer AA, Dennison EM, Syddall HE, Gilboy HJ, Phillips DIW, Cooper C. Type 2 Diabetes, Muscle Strength, and Impaired Physical Function. Diabetes Care. 2005, 28:2541-42.

6. Barbosa AMP. Prevalência e fator de risco para disfunção muscular do assoalho pélvico e incontinência urinária 2 anos após Diabete Mellitus Gestacional. Botucatu: Faculdade de Medicina de Botucatu, Universidade Estadual Paulista; 2006.

7. Cunningham FG, Gant NF, Leveno KJ, et al. Diabetes. In: Cunningham FG, Gant NF, Leveno KJ, et al., eds. Williams Obstetrics. 21st ed. New York, NY: McGraw-Hill. 2001.

8. White P. Classic pages in obstetrics and gynecology. Pregnancy complicating diabetes. American Journal of Medicine. 1949, 7:609-16.

9. Rudge MVC, Calderon IMP, Ramos MD, Rodrigues MA. Diabetes and experimental pregnancy in rats: course of maternal blood glucose levels and its repercussions on the blood glucose levels and pancreas of newborn pups. Braz J Med Biol Res. 1995, 28(2):219-25. 
10. Rudge MVC, Calderon IMP, Ramos MD, Abbade JF, Rugolo LM. Perinatal outcome of pregnancies complicated by diabetes and by maternal daily hyperglycemia not related to diabetes. A retrospective 10-year analysis. Gynecol Obstet Invest. 2000, 50(2):108-12.

11. Americam-Diabetes-Association. Report of the Expert Committee on the Diagnosis and classification of Diabetes Mellitus. Diabetes Care. 2005, 28.

12. Wild S, Roglic G, Green A, Sicree R, King H. Global prevalence of diabetes: estimates for the year 2000 and projections for 2030. Diabetes Care. 2004 May, 27(5):1047-53.

13. Brown JS, Vittinghoff E, Lin F, Nyberg LM, Kusek JW, Kanaya AM. Prevalence and risk factors for urinary incontinence in women with type 2 diabetes and impaired fasting glucose: findings from the National Health and Nutrition Examination Survey (NHANES) 2001-2002. Diabetes Care. 2006 Jun, 29(6):1307-12.

14. Waetjen LE, Liao S, Johnson WO, Sampselle CM, Sternfield B, Harlow SD, et al. Factors associated with prevalent and incident urinary incontinence in a cohort of midlife women: a longitudinal analysis of data: study of women's health across the nation. Am J Epidemiol. 2007 Feb 1, 165(3):309-18.

15. Sarma AV, Kanaya AM, Nyberg LM, Kusek JW, Vittinghoff E, Rutledge B, et al. Risk Factors for Urinary Incontinence Among Women With Type 1 Diabetes: Findings From the Epidemiology of Diabetes Interventions and Complications Study. Urology. 2009, 73 (6):1203-9.

16. Ebbesen MH, Hannestad $\mathrm{YS}$, Midthjell K, Hunskaar S. Diabetes related risk factors did not explain the increased risk for urinary incontinence among women with diabetes. The Norwegian HUNT/EPINCONT study. BMC Urology 2009, 9(11).

17. Izci Y, Topsever P, Filiz TM, Çınar ND, Uludağ C, Lagro-Janssen T. The association between diabetes mellitus and urinaryincontinence in adult women. Int Urogynecol J. 2009, 20:947-52.

18. Sarma AV, Kanaya AM, Nyberg LM, Kusek JW, Vittinghoff E, Rutledge B, et al. Urinary incontinence among women with type 1 diabetes - How common is it? $\mathrm{J}$ Urol. 2009 Mar, 181(3):1224-30. 
19. Kim C, McEwen LN, Sarma AV, Piette JD, Herman WH. Stress urinary incontinence in women with a history of gestational diabetes mellitus. J Womens Health (Larchmt). 2008 Jun, 17(5):783-92.

20. Vinik Al, Maser RE, Mitchell BD, Freeman R. Diabetic autonomic neuropathy. Diabetes Care. 2003 May, 26(5):1553-79.

21. Kiss AC, Lima PH, Sinzato YK, Takaku M, Rudge MVC, Damasceno DC. Animal models for clinical and gestational diabetes: maternal and fetal outcomes. Diabetology \& Metabolic Syndrome. 2009, 1:21.

22. Kim JH, Huang X, Liu G, Moore C, Bena J, Damaser MS, et al. Diabetes slows the recovery from urinary incontinence due to simulated childbirth in female rats. $A m \mathrm{~J}$ Physiol Regul Integr Comp Physiol. 2007 Aug, 293(2):R950-5.

23. Liu G, Lin Y-H, Yamada Y, Daneshgari F. External Urethral Sphincter Activity in Diabetic Rats. Neurourology and Urodynamics 27:429-434. 2008, 27:429-34.

24. Krause MP, Riddell MC, Gordon CS, Imam SA, Cafarelli E, Hawke TJ. Diabetic myopathy differs between Ins2Akita and streptozotocin-induced Type 1 diabetic models. J Appl Physiol 2009, 106:1650-9.

25. Kivela R, Silvennoinen M, Touvra A-M, Lehti TM, Kainulainen H, Vihko V. Effects of experimental type 1 diabetes and exercisetraining on angiogenic gene expression and capillarization in skeletal muscle. The FASEB Journal. 2006, 20(921-29).

26. Rocha MA, Sartori MGF, Simões MDJ, Herrmann V, Baracat EC, G. Rodrigues de Lima, et al. The impact of pregnancy and childbirth in the urethra of female rats. Int Urogynecol J 2007, 18(645-51). 
Bom mesmo é ir a luta com determinação, abraçar a vida com paixão, perder com classe e vencer com ousadia, pois o triunfo pertence a quem se atreve. A vida é muito para ser insignificante.

Charles Chaplin

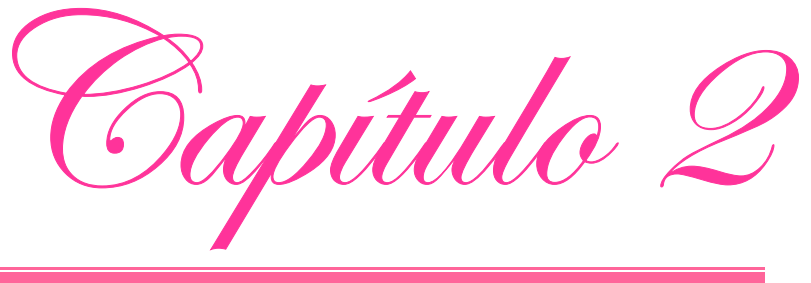




\title{
Morphological changes in muscle mass and in fast- to-slow fiber profile in urethral striated muscle fibers of diabetic pregnant rats.
}

\begin{abstract}
Gabriela Marini ${ }^{1}$, Angélica Mércia Pascon Barbosa1 , Débora Cristina Damasceno ${ }^{1}$, Rodrigo de Aquino Castro ${ }^{2}$, Selma Maria Michelin Matheus ${ }^{3}$, Jorge Milhem Haddad ${ }^{4}$, Suely Kazue Nagahashi Marie ${ }^{5}$, Manoel João Batista Castello Girão ${ }^{2}$, Marilza Vieira Cunha Rudge ${ }^{1 *}$
\end{abstract}

\footnotetext{
${ }^{1}$ Experimental Research Laboratory, Department of Gynecology and Obstetrics, Botucatu Medical School, UNESP - Univ Estadual Paulista, São Paulo, Brazil.

${ }^{2}$ Department of Gynecology, São Paulo Federal University (UNIFESP), São Paulo, Brazil.

${ }^{3}$ Department of Anatomy, Botucatu Biosciences Institute, UNESP - Univ Estadual Paulista, São Paulo, Brazil.

${ }^{4}$ Department of Gynecology, University of São Paulo (USP), São Paulo, Brazil.

${ }^{5}$ Department of Neurology, Clínicas Hospital, School of Medicine, University of São Paulo (USP), São Paulo SP, Brazil.
}

* Correspondence: Marilza Vieira Cunha Rudge. Experimental Research Laboratory, Department of Gynecology and Obstetrics, Botucatu Medical School, UNESP - Univ Estadual Paulista CEP 18618000 - Botucatu, São Paulo, Brazil. E-mail address: marilzarudge@ig.com.br

Este capítulo foi redigido de acordo com as normas de publicação da revista Internacional Urogynecology Journal, para a qual será submetido. 


\section{Abstract}

The aim of this study was to evaluate the morphological alterations of the urethral striated muscle and type I and II muscle fibers in diabetic pregnant rats that underwent cesarean section. Twenty female Wistar rats were distributed in four experimental groups of five rats: virgin (control), pregnant (control), diabetic virgin (control), and diabetic pregnant. Diabetes was induced by streptozotocin administration. The rats were lethally anesthetized and the urethra and vagina were extracted as a unit. Cryostat sections of $6-\mu \mathrm{m}$ thickness were cut and stained with hematoxilin-eosin and immunohistochemical procedures were performed and subjected to morphological and semi-quantitative analysis. In comparison with muscle from the three control groups, urethral striated muscle from diabetic pregnant rats presents with the following variations: thinning and atrophy, disorganization and disruption associated with co-localization of fast and slow fibers and a steady decrease in the proportion of fast to slow fibers. Our results indicate that diabetes and pregnancy impair the urethral striated muscle and alter the distribution of its fiber types.

Keywords: diabetes, pregnancy, striated muscle fiber, urethra 


\section{Introduction}

Diabetes mellitus (DM) during pregnancy was associated with high levels of urinary incontinence (UI) and pelvic floor muscle dysfunction two years after cesarean section. The risk factors for pelvic floor muscle dysfunction among these women were related to high newborn weight and high maternal weight gain during pregnancy as a result of Gestational Diabetes mellitus (GDM). Furthermore, the risk factors for UI were indirectly influenced by GDM and pelvic floor muscle dysfunction. This framework confirms an association between GDM and subsequent pelvic floor muscle dysfunction two years following cesarean section [1] .

Data from an epidemiological study in Norway showed that risk factors related to DM did not explain the increased risk for UI among women with DM. This study revealed associations between DM management and complications and $\mathrm{UI}$, but the biological and laboratory parameters do not appear to explain the previously documented association. However, associations were found between $\mathrm{UI}$ and some clinical correlates of DM [2].

DM has been established as an independent risk factor for UI, the involuntary leakage of urine [3]. DM causes debilitating and devastating complications not only during pregnancy but also after delivery [4]. Outside pregnancy, an association has been found between DM type 1 
or 2 and a high prevalence of UI (30-60\%) [5]. The risk conferred by DM appears to be in addition to other recognized risk factors for $\mathrm{UI}$ [6]. Current theories on the pathophysiology of lower urinary tract complications of DM include myopathic components of the pelvic floor [7, 8].

The role of pregnancy and childbirth in determining $\mathrm{UI}$ is still debatable. Many hypotheses attempt to explain the origin of UI during pregnancy, its association with vaginal delivery, and the protective role of cesarean section. The increased concentration of collagen and decrease in muscle fibers in the urethra of female rats after vaginal delivery may be one of the mechanisms in the development of $\mathrm{UI}$ in women [9]. However, Barbosa et al., [10] showed that elective cesarean section was not sufficient to prevent UI two years postpartum.

$\mathrm{UI}$ is a debilitating disorder caused by malfunctioning of the urethral sphincter. Anatomical and histological properties of the sphincter, its innervations, and supporting structures are explained in relation to the closing mechanism of the bladder outlet [11]. Stronger clinical support for a causal relationship between decreased thickness of the urethral sphincter and UI has been provided [12].

Striated fibers are the dominating muscle component in the midurethra [13] and have been classified into two major groups: type I (slowtwitch) and type II (fast-twitch) based on the presence of myosin heavy 
chain (MHC) isoforms. Slow-twitch type I muscle fibers are rich in mitochondria, present high oxidative capacity, and are resistant to fatigue. Conversely, fast-twitch type II muscle fibers have high glycolytic metabolism and fatigue easily [14]. The role of each fiber type in contraction of the striated sphincter is controversial and likely depends on the species studied and the method used for the determination of fast and slow types [15].

Given the high prevalence of UI among women with previous GDM, and considering that striated muscle is one of the two most important tissue types affected by insulin resistance and type 2 diabetes, the purpose of the present study was to evaluate the urethral striated muscle fiber composition in the urethra of the diabetic pregnant rat to better understand the influences of diabetes and pregnancy on the urethral muscle fibers. Alterations in the two basic types of urethral striated fibers: type I (slow) and type II (fast) in urethral muscle of pregnant diabetic rat were analyzed. We hypothesized that diabetes and pregnancy would detrimentally affect normal function of urethral striated muscle in rats, providing a model for further studies related to UI.

\section{Materials and Methods}

This study was developed in the Experimental Research Laboratory of the Department of Gynecology and Obstetrics, Botucatu 
Medical School, UNESP-Univ Estadual Paulista, São Paulo, Brazil. Prior to the study, ethical approval was obtained from the Institutional Animal Care and Use Committee on Animal Experimentation of Botucatu Medical School-UNESP (Process number 668).

Six-week-old female and nine-week-old male Wistar rats, weighing approximately $180 \mathrm{~g}$ and $220 \mathrm{~g}$, respectively, were allowed to adapt to the laboratory for seven days. The rats were kept in collective cages under controlled conditions of temperature $\left(22 \pm 3^{\circ} \mathrm{C}\right)$, light $(12$ hour light/dark cycles) and relative humidity $(60 \pm 5 \%)$. The animals were fed with laboratory chow $\left(\right.$ Purina $^{\circledR}$ ) and tap water ad libitum and cared for in accordance with the principles of the Guide for Care and Use of Experimental Animals.

The adult female rats were distributed among four groups:

Group 1: five virgin rats euthanized on the $28^{\text {th }}$ day of the experiment; Group 2: five pregnant rats that underwent cesarean section on day 21 of pregnancy and were euthanized immediately;

Group 3: five diabetic virgin rats euthanized on the $28^{\text {th }}$ day of diabetes induction;

Group 4: five diabetic pregnant rats that underwent cesarean section on day 21 of pregnancy and were euthanized immediately. 


\section{Induction of Diabetes}

Diabetes was induced by streptozotocin (STZ - SIGMA Chemical Company, St. Louis, MO, USA) seven days before mating. A dose of 40 $\mathrm{mg} / \mathrm{kg}$-body weight was administered by intravenous route to produce a permanent severe diabetic state. Blood glucose levels were measured at the beginning and end of the experimental period using glucose oxidase reagents strips (One-Touch Ultra Johnson \& Johnson ${ }^{\circledR}$, Milpitas, CA, USA). Only rats with glucose levels greater than $200 \mathrm{mg} / \mathrm{dL}$ were assigned to the diabetic groups [16].

Female rats (pregnant and diabetic pregnant groups) were mated overnight with non-diabetic male rats. The morning when sperm was found in the vaginal smear was designated gestational day 0 .

On day 21 of pregnancy, fed rats were weighed in order to determine maternal weight gain (final weight - initial weight) and lethally anesthetized with sodium thiopental (Thiopentax ${ }^{\circledR} 3 \%$ ). Following trichotomy of the abdominal region, the animal was placed in the dorsal decubitus position, and its ribs were fixed to the surgery table. Laparotomy was carried out by a midline incision beginning at the xiphoid cartilage and ending at the pubis. The intestinal loops were moved cranially for uterus exposure. Hysterectomy was carried out by sectioning of the ligament, artery and ovarian vein and incision of the 
uterine body above the cervix. Incisions were then placed throughout the entire extension of the uterine horns, on their free margin and in the most avascular area. The fetus, amniotic sac and placenta were removed by slight traction (Figure 1). Following birth, offspring were weighed, anesthetized and euthanized.

The urethra and vagina were extracted as a unit to facilitate their handling (Figure 2). Each unit was immediately placed in a position suitable for transverse sectioning and was frozen with liquid nitrogen. Samples were stored at $-80^{\circ} \mathrm{C}$ until sectioning and staining. Cryostat sections of 6- $\mu \mathrm{m}$ thickness were cut and stained with hematoxilin-eosin (H\&E) to visualize nuclei, membranes, cytoplasm and connective tissue. Immunohistochemical procedures were performed on $6 \mu \mathrm{m}$ thick serial cross-sections to visualize fast and slow myosin heavy chains (MHCfast and MHCslow). Antibodies WB-MHCf Novocastra (1:120) and WB-MHCs Novocastra (1:160) were used.

\section{Data analysis}

Study of the rat urethra was performed by morphological analysis, and a semi-quantitative method was used to analyze immunohistochemical staining of fast and slow type skeletal muscle fibers. 
For this analysis, fast and slow type fibers were considered separately. The intensity of immunolocalization was evaluated by two independent readers and averaged. Striated muscle of the urethra was analyzed based on the following parameters: the presence of each type of fiber throughout circumference of the layer $(++++$ if layer complete throughout circumference and + if not complete ), the thickness of muscle fiber layers $(++++$ for thickness of more than five layers and + for thickness of one muscle fiber layer) and the degree to which the layers maintained a normal anatomic localization $(++++$ normal anatomic localization, ++ intermediate anatomic localization, + loss of normal anatomic localization).

The scores for presence in circumference, thickness, and anatomic localization, based on the above criteria, were multiplied for each fiber type. The obtained values for fast fibers were then divided by those for slow fibers to establish the fast/slow index.

Convenient transformations (Neperian log) were performed in order to make offspring weight, maternal weight gain and glycemic data adjust to a symmetrical distribution and homogeneous variance. Analysis of Variance (ANOVA) was used followed by Tukey's Multiple Comparison Test. Statistical significance was considered as $p<0.05$. Data were expressed as mean \pm standard error of mean (SEM). 


\section{Results}

\section{Urethral histology}

The transverse sections of the central part of the urethra in the virgin group showed different layers from the lumen to the periphery: stratified squamous epithelium (arrow), lamina propria (*) spongy vascular plexus $(P)$, smooth muscle: longitudinal (1) and circular (2) fibers and striated muscle (3) (Figure 3).

\section{Morphological and semi-quantitative analysis of striated muscle fiber composition in the rat urethra}

\section{Virgin group}

H\&E-stained transverse cross-sections of the striated muscle fiber revealed many layers and compact outer circular layers. The fibers were long, with similar thickness throughout the circumference (Figure 4-A).

Immunohistochemical staining revealed that the striated myofibers predominantly expressed the fast myosin heavy chain isoform. The layer containing fast fibers was thick and the fibers were present throughout the outer circular layer (++++) (Figure 4-B). The proportion of fast to slow fibers was 4:1 (Table 1). A thin, inner circular layer of slow striated muscle fibers was observed $(+)$ with individual fibers being small and thin (Figure 4-C). The image suggested different localization patterns for 
each type of fibers, with fast fibers being outermost and slow fibers innermost.

\section{Pregnant group}

H\&E-stained transverse cross-section revealed that the appearance of the striated muscle layer was similar to that of the control group. An increase in connective tissue separated the fibers from one another. The most important finding in this group was the great interstitial spaces found between fibers (Figure 5-A).

Immunohistochemical staining revealed that the distribution of fast and slow fibers and the proportion between them were similar to those of the virgin group (4:1) (Figure 4-E-F) (Table 1).

\section{Diabetic virgin group}

H\&E-stained transverse cross-section showed that the circular annulus was lost. There was obvious fiber thinning and atrophy, and the striated muscle was disrupted. There were few complete layers of striated muscle (Figure 5-B).

Immunohistochemical staining revealed that the specific localization for each type of fiber was lost, with co-localization of fast and slow fibers and a decrease in the proportion of fast to slow fibers for 1.5:1 (Figure H-I) (Table 1). 


\section{Diabetic pregnant group}

H\&E-stained transverse cross-section showed that the circular annulus was lost. The fiber layers were thin, atrophic, and disorganized, and the striated muscle was disrupted. The findings were similar to those of the pregnant group in relation to the increase in connective tissue separating the fibers from one another and the great interstitial spaces (Figure 5-C).

Immunohistochemical staining here also revealed a loss of specific localization for each type of fiber, with co-localization of fast and slow fibers and a decrease in the proportion of fast to slow fibers for $1.5: 1$ (Figure 6-B-C) (Table 1).

\section{Maternal and perinatal results}

Mean maternal weight gain and offspring weights from the pregnant group showed no significant statistically differences as compared to those from diabetic pregnant rats (Table 2).

The diabetic virgin and diabetic pregnant groups presented with increased glycemia during pregnancy as compared to virgin and pregnant groups $(p<0.05)($ Table 2$)$. 


\section{Discussion}

The goal of the present study was to gain a more comprehensive understanding of striated muscle fiber composition in the urethra of the pregnant diabetic rat and the proportion between two basic types of urethral striated muscle fibers: type I (slow-twitch) and type II (fasttwitch). It is of paramount importance not only to understand the effects of DM and pregnancy on striated muscle but also to develop new therapeutic strategies. Human studies are often limited due to ethical concerns, to the challenges of obtaining large tissue samples, and to the use of strictly-managed control groups. To better understand how different risk factors for UI affect the morphological properties of striated muscle, animal models are useful as the experiments are conducted under controlled conditions [17].

The striated muscle fiber composition of the urethra of the diabetic pregnant rat is discussed along with the importance of considering experimental conditions, and the possibility to include three control groups: virgin, pregnant and diabetic virgin. With this methodology, it was possible to separately analyze the influence of diabetes and pregnancy. Of particular note, we found that, relative to these three groups, the urethral striated muscles of diabetic pregnant rats present with the following: thinning and atrophy, disorganization, disruption of the 
circular annulus associated with co-localization of fast and slow fibers, and a steady decrease in the proportion of fast to slow fibers (fast:slow 1.5:1). An increase in connective tissue separating the fibers from one another, as in the interstitial spaces between fibers, occurred as an effect of pregnancy on urethral muscle.

Thinning and atrophy, disorganization, and disruption of the circular annulus of striated muscle were extensive damages caused by diabetes $[18,19]$. DM was related to accumulation of reactive oxygen species and tissue ischemia can interactively or independently contribute to the myopathy causes of skeletal muscle dysfunctions [20-21]. In our research laboratory, the relationship between oxidative stress and diabetes in pregnant rats was confirmed by Damasceno et al., [22].

In analyzing this data, we were able to explain that extensive damage to striated muscle fibers characterized by reduced skeletal muscle mass and altered myofiber composition in diabetic pregnant rats links diabetes and pregnancy to UI. This specific loss of skeletal muscle mass is referred to as diabetic myopathy [23]. The present study confirms previous findings that diabetic myopathy and pregnancy are involved in the pathogenesis of urinary incontinence.

Differences in fiber type composition were detected in urethral striated muscle in diabetic pregnant rats in comparison to control groups. In the studied animals, the expression profile of fast to slow fibers 
revealed two main differences. First, fast fibers lost their great predominance in relation to slow fibers. Second, the fast fibers lost their typical architecture, and the tissue was transformed into a mixture of slow and fast fibers. To the best of our knowledge, the findings are here described for the first time and may be labeled as a diabetic pregnant myopathy. Studies in animal models have shown a strong relationship between muscle fiber type and the development of diabetes [24].

Skeletal muscle is recognized not only for being responsible for movement but also for its function as the largest organ for glucose utilization. Our finding of increased type I slow-type fibers could be related to the abundant availability of lipids [25]. It is well established that changes in muscle fiber composition are often associated with glucose metabolism, diabetes and obesity [26]. Since muscle is a main site of glucose uptake, reduced muscle mass and changes in fiber type composition may directly impair acute glucose utilization. Skeletal muscle can adapt to functional and metabolic demands by remodeling with fibertype switches to maintain a normal energy balance and utilization of nutrients.

Chen et al., [14] confirmed a higher proportion of type I fibers and the presence of fast-to-slow fiber-type switching, which appears to be dissociated from the expected change in oxidative capacity. Our findings suggest that DM alters the profile of fast-to-slow fibers in the urethral 
striated muscle of diabetic pregnant rats and that an eventual fiber-type switching could be present. The nature of the mechanism related to this altered fiber type in our model requires further investigation.

As the primary function of the lower urinary tract is the storage and expulsion of urine at the appropriate times, changes in the striated muscle composition could be related to the loss of type II fibers [27] or to the transformation of most type II fibers into type I fibers [28]. Given the limitations of this study, its results could represent muscle changes according to glucose levels.

The damages revealed by morphological studies demonstrate the impact of the association between diabetes and pregnancy on urethral striated muscle fibers, as three of the factors related to altered urethral striated muscle in diabetes and pregnancy - maternal weight gain, offspring weight and trauma related to vaginal delivery - were controlled. However, the results of our study should be interpreted with awareness of the following limitations: rats are quadrupeds; they have tails with associated musculature; and their bladders are abdominal rather than pelvic organs [18].

It is well-established that the functional capacity of a muscle is impaired when its fibers are injured [29]. As the function of skeletal muscle is determined by muscle mass and fiber composition [14], our exciting results provide evidence that diabetes and pregnancy injure striated 
muscle and alter its fast and slow fiber composition. These data suggest that diabetic pregnant rats may present altered contractility of urethral striated muscle, supporting the high $\mathrm{UI}$ prevalence in women with previous GDM, two years after cesarean section [1].

The importance of this study is support of the previous hypothesis that diabetes and pregnancy detrimentally affect the normal function of urethral striated muscles in rats, providing a model for further studies.

\section{Conclusion}

This study allowed us to describe the morphological changes in muscle mass and in the fast-to-slow fiber profile in urethral striated muscle fibers of diabetic pregnant rats. The urethral striated muscles were found to be thin and atrophic, disorganized, and disrupted. They were associated with the loss of normal anatomic localization for each fiber type with co-localization of fast and slow and with the loss of predominance in the expression of fast fibers in relation to slow fibers. This suggests that $\mathrm{UI}$ in diabetic pregnant women may be attributed in part to the changes in urethral striated muscles. 


\section{Acknowledgements}

Financial support was provided by a fellowship from Fundação de Amparo à Pesquisa do Estado de São Paulo (FAPESP), at Gabriela Marini (Grant/Process Number 2008/00989-4). The authors thank Research Center in Neurology (University of São Paulo) by technical assistance.

\section{Competing interests}

The authors declare that no competing interests exist. 


\section{References}

1. Barbosa AMP (2006) Prevalência e fator de risco para incontinência urinária e disfunção muscular do assoalho pélvico dois anos após Diabete Melito gestacional. Botucatu-SP: Faculdade de Medicina de Botucatu, Universidade Estadual Paulista UNESP

2. Ebbesen MH, Hannestad YS, Midthjell K, Hunskaar S (2009) Diabetes related risk factors did not explain the increased risk for urinary incontinence among women with diabetes. The Norwegian HUNT/EPINCONT study. BMC Urology 9:11

3. Danforth KN, Townsend MK, Curhan GC, Resnick NM, Grodstein F (2009) Type 2 Diabetes mellitus and risk of stress, urge and mixed urinary incontinence. J Urol 181(1):193-7

4. Pimenta WP, Calderon IMP, Cruz NS, Santos ML, Aragon FF, Padovani CR (2004) Subclinical anormalities o glucose metabolism in Brazilian women with a history of gestational Diabetes mellitus. Acta Obstet Gynecol Scand 83:1152-8

5. Luber KM, Boero S, Choe JY (2001) The demographics of pelvic floor disorders: current observations and future projctions. Am J Obstet Gynecol 184:1496-501

6. Bump RC, Norton PA (1998) Epidemiology and natural history of pelvic floor dysfunction. Obstet Gynecol Clin North Am 25(4):723-46

7. Liu G, Daneshgari F (2005) Temporal diabetes-and diuresis-induced remodeling of the urinary bladder in the rat Am J Physiol Regul Integr 291(3):R83743.

8. Daneshgari F, Moore C (2006) Diabetic uropathy. Semin Nephrol 26:182-5

9. Rocha MA, Sartori MG, De Jesus Simões M, Herrmann V, Baracat EC, Girão MJBC, et al (2007) The impact of pregnancy and childbirth in the urethra of female rats. Int Urogynecol J Pelvic Floor Dysfunct 18(6):645-51

10. Barbosa A, Rudge M, Rudge C, Assis L, Marini G, Modotte W, et al (2008) Does the elective cesarean protect the woman from the occurrence of urinary incontinence and from pelvic floor muscle dysfunction?. The FIEP Bulletin 78:202-4

11. Heesakkers JP, Gerretsen RR (2004) Urinary incontinence: sphincter functioning from a urological perspective. Digestion 69(2):93-101

12. Morgan DM, Umek W, Guire K, Morgan HK, Garabrant A, DeLancey JOL (2009) Urethral sphincter morphology and function with and without stress incontinence. J Urol 182:203-9 
13. Andersson PO, Malmgren A, Uvelius B (1990) Functional responses of different muscle types of the female rat urethra in vitro. Acta Physiol Scand 140:36572

14. Chen M, Feng HZ, Gupta D, Kelleher J, Dickerson KE, Wang J, et al (2009) $\mathrm{G}$ (s)alpha deficiency in skeletal muscle leads to reduced muscle mass, fiber-type switching, and glucose intolerance without insulin resistance or deficiency. Am J Physiol Cell Physiol 296(4):C930-40

15. Elbadawy A (1996) Functional anatomy of organs of micturition. Urol Clin North Am 23:177-210

16. Calderon IMP, Rudge MVC, Ramos MD, Peraçoli JC (1999) Estudo longitudinal, bioquímico e histoquímico de placentas de ratas diabéticas: relação com a macrossomia e o retardo de crescimento intra-uterino. Rev Bras Ginecol Obstet 21:91-8

17. Abramowitch SD, Feola A, Jallah Z, Moalli PA (2009) Tissue mechanics, animal models, and pelvic organ prolapse: a review. Eur J Obstet Gynecol Reprod Biol 144 Suppl 1:S146-58

18. Kim JH, Huang X, Liu G, Moore C, Bena J, Damaser MS, et al (2007) Diabetes slows the recovery from urinary incontinence due to simulated childbirth in female rats. Am J Physiol Regul Integr Comp Physiol 293(2):R950-5

19. Gasbarro G, Lin DL, Vurbic D, Quisno A, Kinley B, Daneshgari F, et al (2009) Voiding function in obese and type 2 diabetic female rats. Am J Physiol Renal Physiol 298(1):F72-7

20. Beshay E, Carrier S (2004) Oxidative stress plays a role in diabetes-induced bladder dysfunction in a rat model. Urology 64(5):1062-7

21. De Angelis KL, Cestari IA, Barp J, Dall'Ago P, Fernandes TG, de Bittencourt $\mathrm{PI}$, et al (2000) Oxidative stress in the latissimus dorsi muscle of diabetic rats. Braz J Med Biol Res 33(11):1363-8

22. Damasceno DC, Volpato GT, Calderon IMP, Rudge MVC (2002) Oxidative stress and diabetes in pregnant rats. Animal Reprod Science 72(3-4):235-44

23. Krause MP, Riddell MC, Gordon CS, Imam SA, Cafarelli E, Hawke TJ (2009) Diabetic myopathy differs between Ins2Akita+/- and streptozotocin-induced Type 1 diabetic models. J Appl Physiol 106(5):1650-9

24. Schuler M, Ali F, Chambon C, Duteil D, Bornert JM, Tardivel A, et al (2006) PGC1alpha expression is controlled in skeletal muscles by PPARbeta, whose ablation results in fiber-type switching, obesity, and type 2 diabetes. Cell Metab $4(5): 407-14$ 
25. de Wilde J, Mohren R, van den Berg S, Boekschoten M, Dijk KW, de Groot P, et al (2008) Short-term high fat-feeding results in morphological and metabolic adaptations in the skeletal muscle of C57BL/6J mice. Physiol Genomics $19 ; 32(3): 360-9$

26. Oberbach A, Bossenz Y, Lehmann S, Niebauer J, Adams V, Paschke R, et al (2006) Altered fiber distribution and fiber-specific glycolytic and oxidative enzyme activity in skeletal muscle of patients with type 2 diabetes. Diabetes Care 29(4):895900

27. Pandit M, Delancey JOL, Ashton-Miller, lyengar J, Blaivas M, Peruchini D (2000) Quantification of intramuscular nerves within the female striated urogenital sphincter muscle. Obstet Gynecol 95:797-800

28. Fujimoto S, Watanabe J, Ogawa R, Kanamura S (1994) Age related changes in fiber number, fiber size, fiber type composition and adenosine triphosphatase activity in rat soleus muscle. Ann Anat 176:429-35

29. Gregorevic P, Plant DR, Stupka N, Lynch GS (2004) Changes in contractile activation characteristics of rat fast and slow skeletal muscle fibers during regeneration. J Physiol 15;558(Pt 2):549-60 


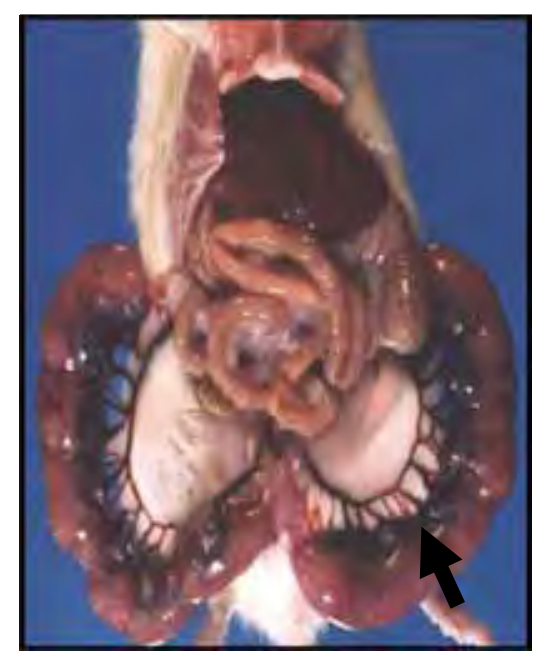

Figure 1. Photograph of anesthetized female rat showing the uterine horns. Arrow points the place where the horns were opened and the fetuses withdraw.

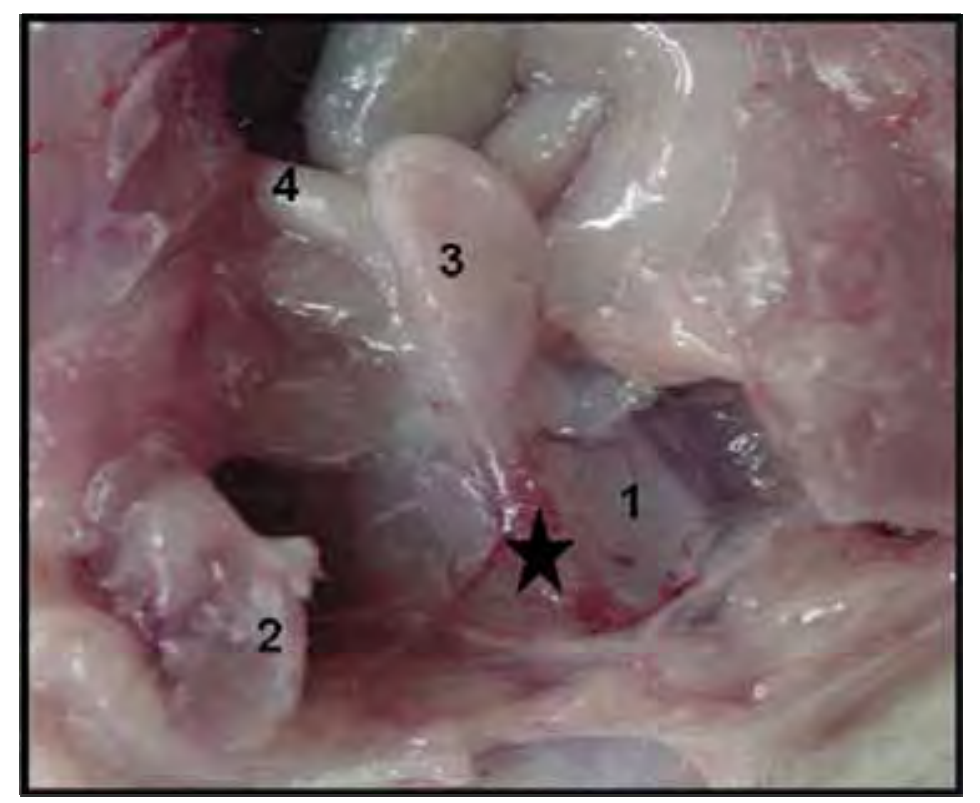

Figure 2. Photograph of pelvic region in female rat. Vagina (1), pubic symphysis(2), bladder (3), uterine horn (4), urethra (*). 


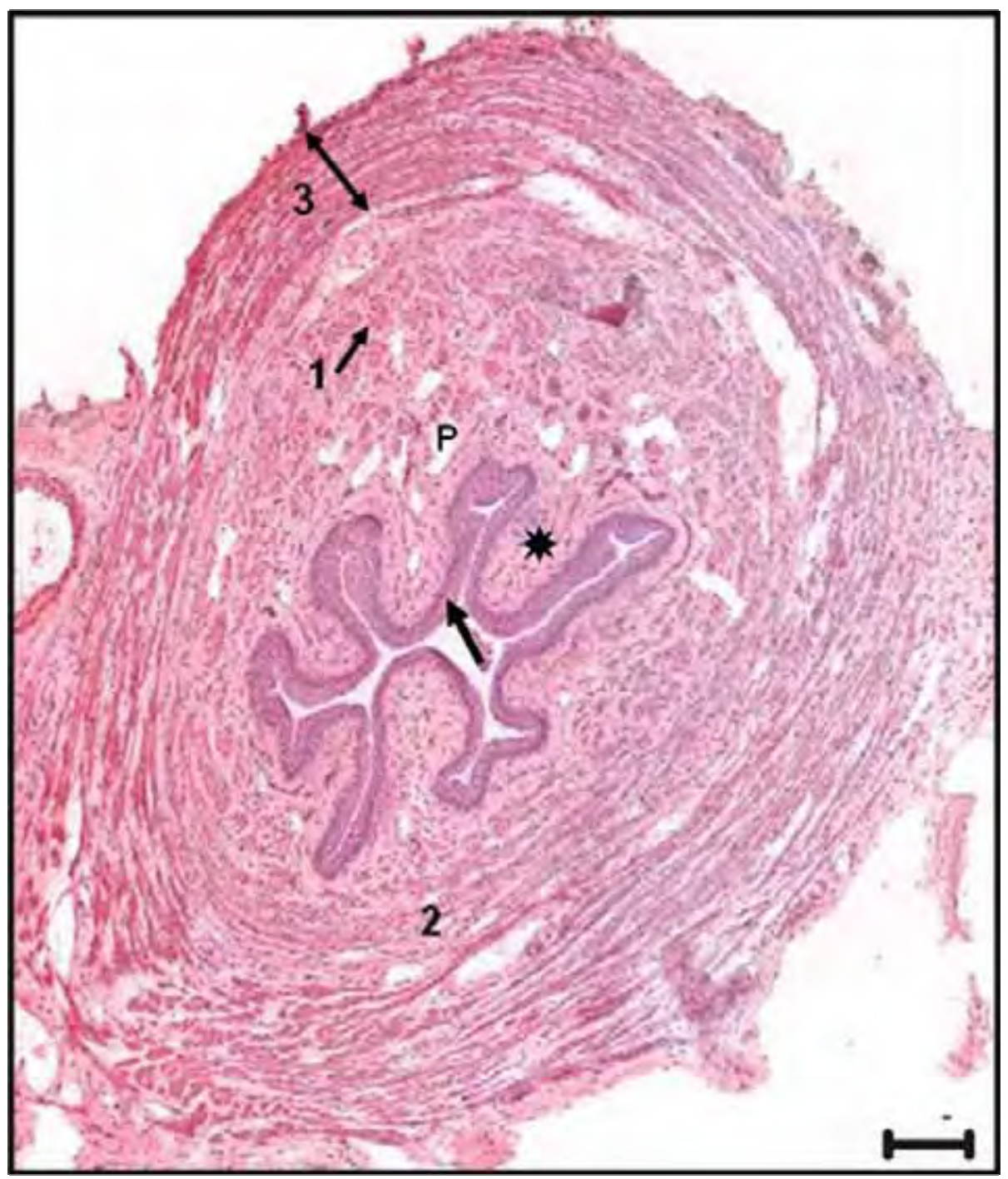

Figure 3. Microphotograph of transverse section of the central part of the urethra in a virgin female rat. Different layers are evident from the lumen to the periphery: epithelium (arrow), lamina propria (*), spongy vascular plexus (P), smooth muscle: longitudinal (1) and circular (2) oriented fibers, and striated muscle (3). H\&E stained. Scale bar $=100 \mu \mathrm{m}$. 
A
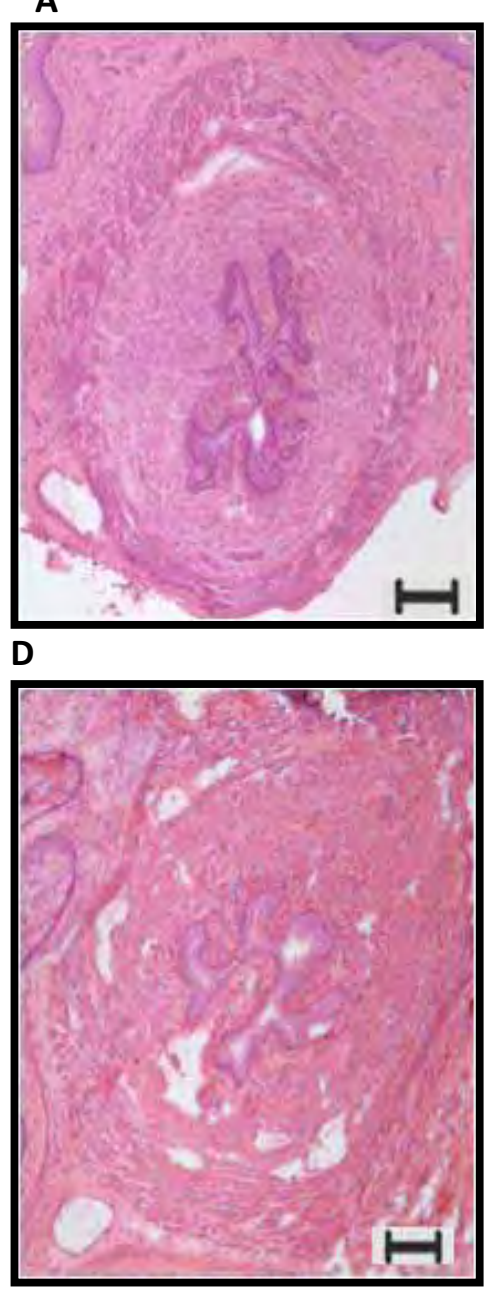

$\mathbf{G}$

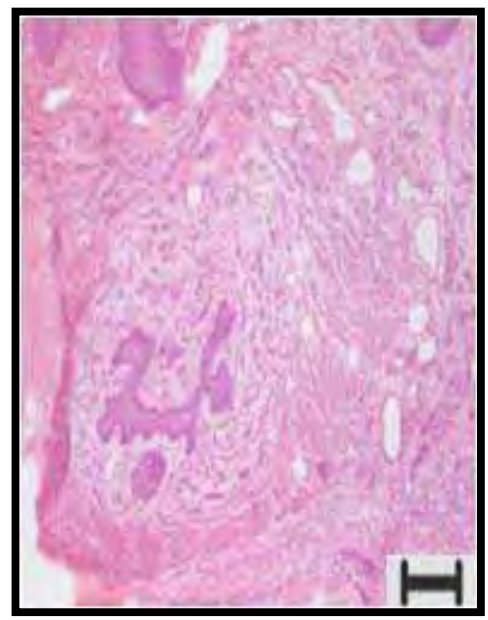

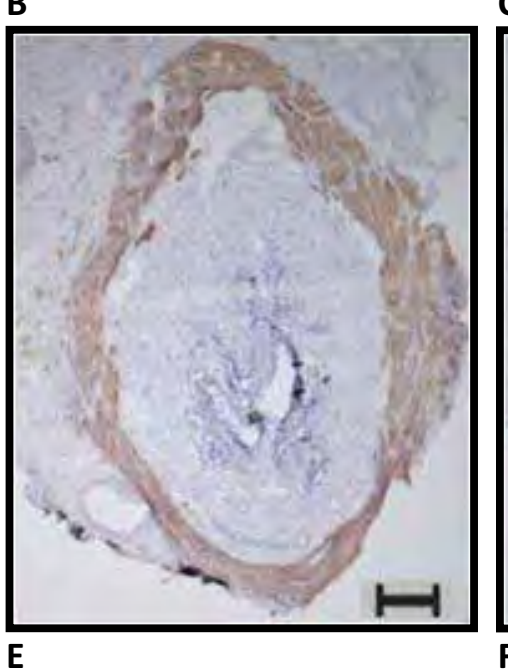

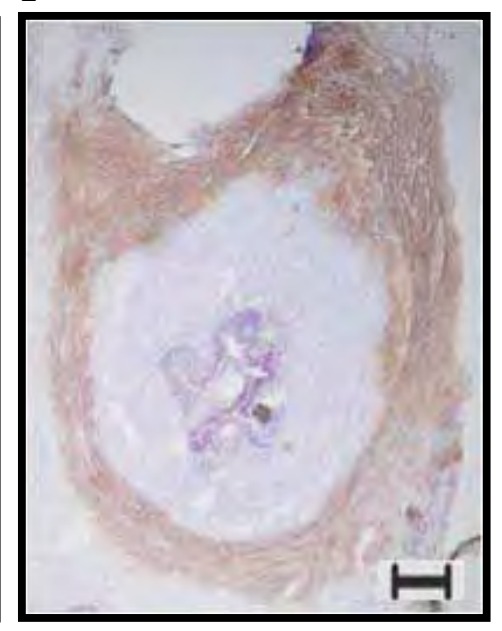

$\mathbf{H}$

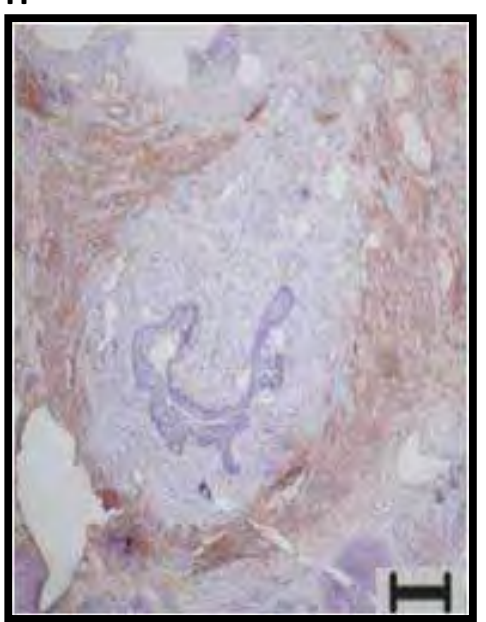

C
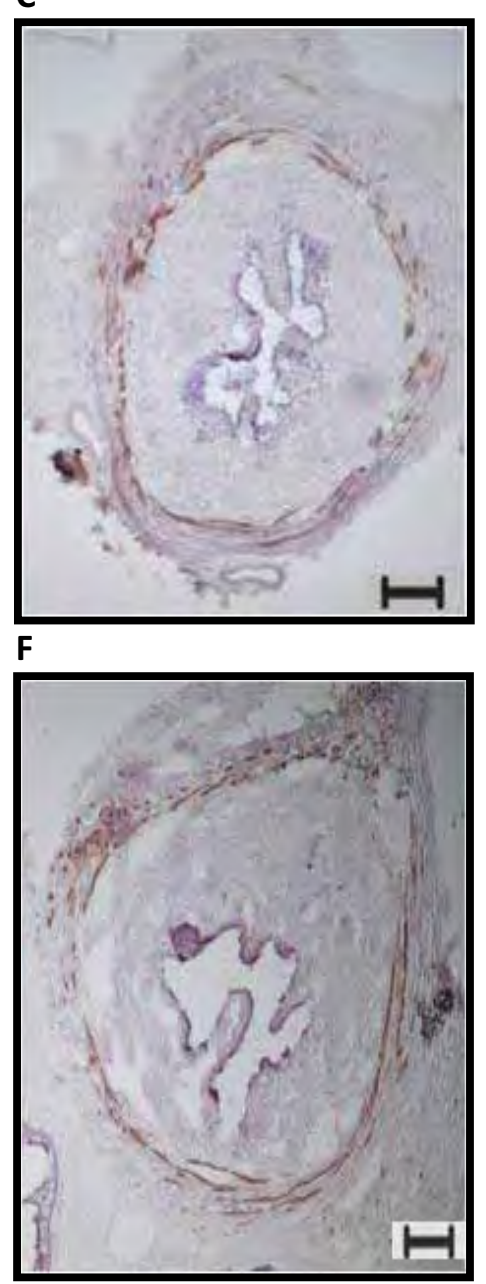

I

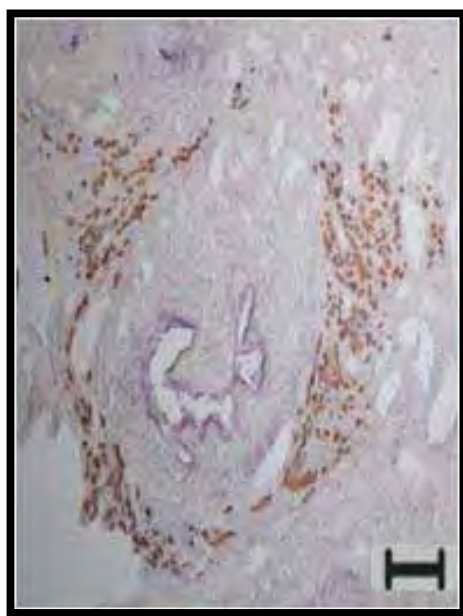

Figure 4. Microphotographs of transverse section of the urethra in virgin group $(A, B, C)$, pregnant group $(D, E, F)$, diabetic virgin group $(G$, $H, I)$. H\&E stained (H\&E); immunohistochemical staining to visualize fast (FAST) and slow (SLOW) myosin heavy chain (MHCf, MHCs) in the striated muscle fibers. Scale bar $=100 \mu \mathrm{m}$ 

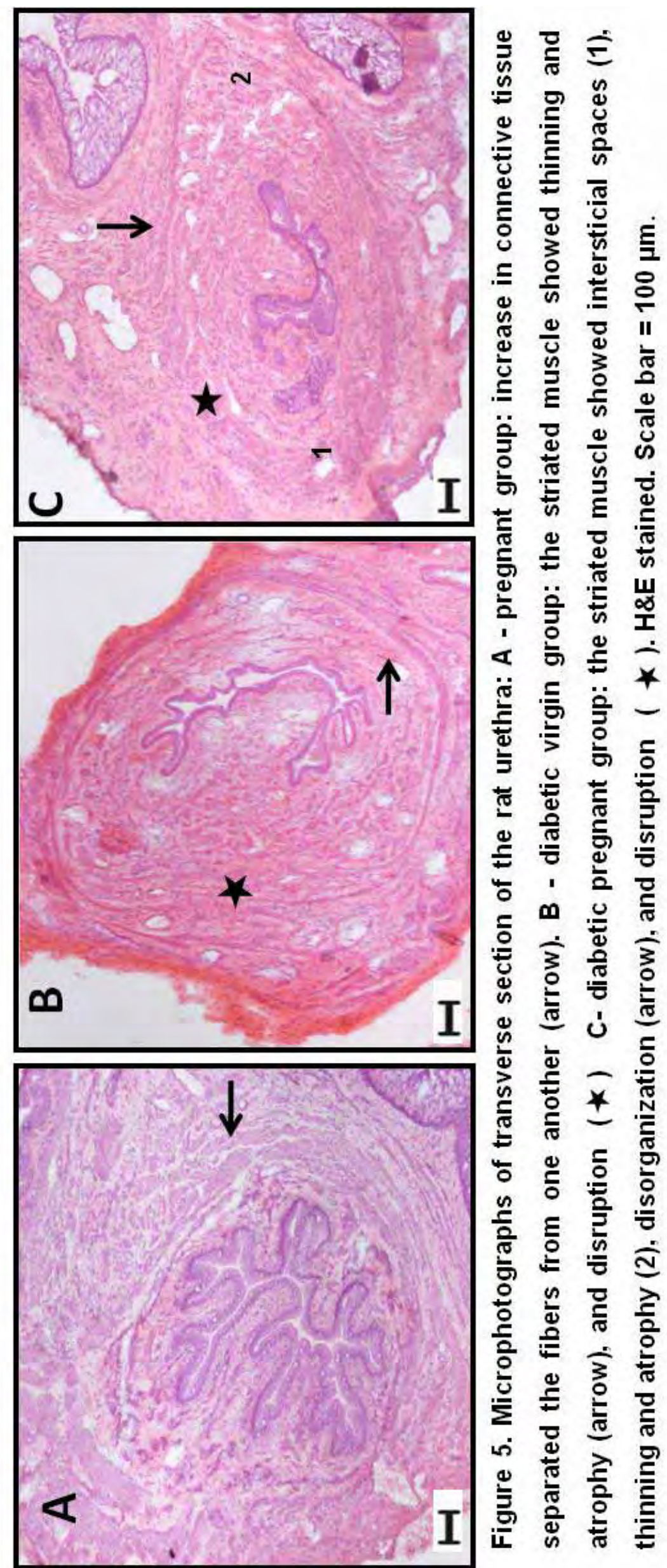


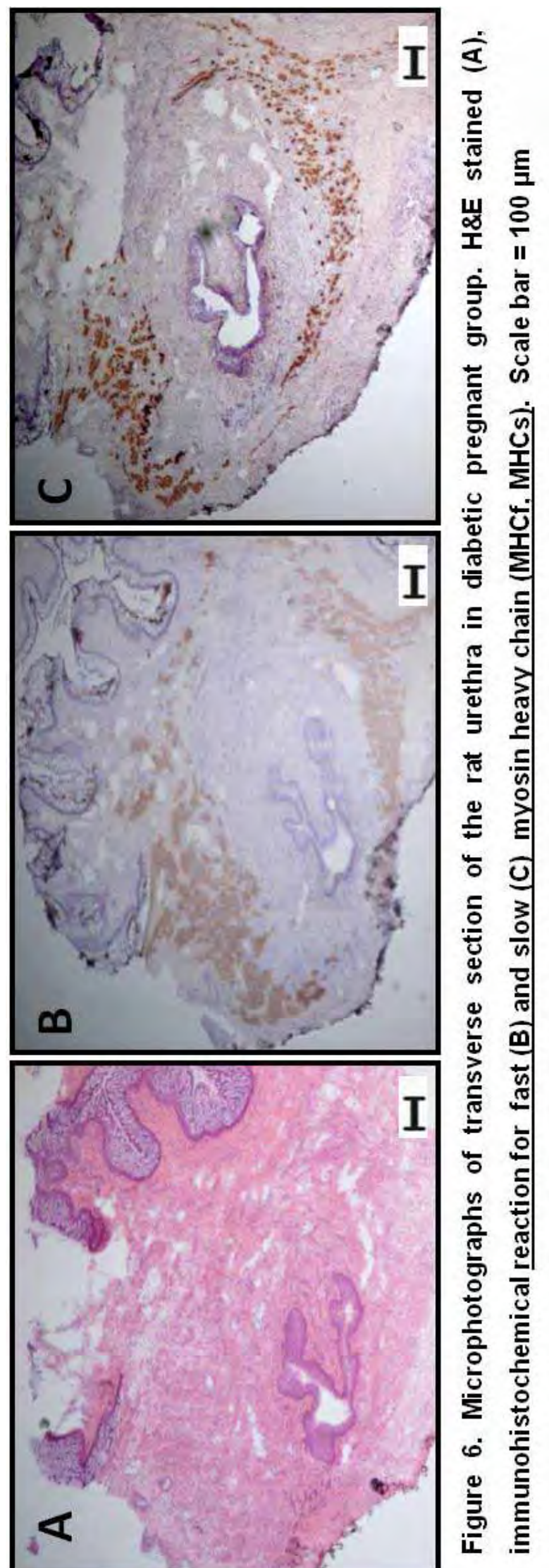


Table 1. Semi-quantitative analysis of slow and fast fibers according the presence of each type of fiber throughout circumference of the layer; thickness of the muscle fiber layer; the degree to which the layers maintained a normal anatomic localization; fast index; slow index; and fast:slow index in each group.

\begin{tabular}{|c|c|c|c|c|}
\hline Groups & Virgin & Pregnant & $\begin{array}{c}\text { Diabetic } \\
\text { Virgin }\end{array}$ & $\begin{array}{l}\text { Diabetic } \\
\text { pregnant }\end{array}$ \\
\hline $\begin{array}{c}\text { Fast } \\
\text { Throughout } \\
\text { circumference/thickness/ } \\
\text { normal anatomic } \\
\text { localization }\end{array}$ & $++++/++++/++++$ & $++++/++++/++$ & $+++/++++/+$ & $+++/+++/+$ \\
\hline $\begin{array}{c}\text { Slow } \\
\text { Throughout } \\
\text { circumference/thickness/ } \\
\text { normal anatomic } \\
\text { localization }\end{array}$ & $++++/+/++++$ & $++++/+/++$ & $+++/+++/+$ & $+++/++/+$ \\
\hline Fast index & 64 & 32 & 12 & 9 \\
\hline Slow index & 16 & 8 & 9 & 6 \\
\hline Fast: Slow index & $4: 1$ & $4: 1$ & $1.5: 1$ & $1.5: 1$ \\
\hline
\end{tabular}


Table 2. Maternal weight gain $(\mathrm{g})$ and offspring weight $(\mathrm{g})$ in pregnant and diabetic pregnant groups. Maternal glycemia $(\mathrm{mg} / \mathrm{dL})$ from virgin, pregnant, diabetic virgin and diabetic pregnant groups at beginning and end of the experimental period.

\begin{tabular}{|c|c|c|c|c|}
\hline Groups & Virgin & Pregnant & $\begin{array}{c}\text { Diabetic } \\
\text { Virgin }\end{array}$ & $\begin{array}{l}\text { Diabetic } \\
\text { pregnant }\end{array}$ \\
\hline $\begin{array}{c}\text { Maternal weight } \\
\text { gain (g) }\end{array}$ & & $115.4 \pm 16.3$ & & $72.2 \pm 21.5$ \\
\hline $\begin{array}{l}\text { Offspring weight } \\
\text { (g) }\end{array}$ & & $82.6 \pm 10.6$ & & $67.2 \pm 14.3$ \\
\hline $\begin{array}{l}\text { Maternal glycemia } \\
(\mathrm{mg} / \mathrm{dL}) \text { beginning } \\
\text { of experiment }\end{array}$ & $81.0 \pm 4.4$ & $112.8 \pm 4.0$ & $568.4 \pm 38.0^{*}$ & $544.0 \pm 36.8^{*}$ \\
\hline $\begin{array}{l}\text { Maternal glycemia } \\
(\mathrm{mg} / \mathrm{dL}) \text { end of } \\
\text { experiment }\end{array}$ & $81.6 \pm 5.0$ & $82.6 \pm 7.7$ & $584.8 \pm 33.9^{*}$ & $497.8 \pm 60.4^{*}$ \\
\hline
\end{tabular}

Values are reported as mean \pm SEM.

${ }^{*} p<0.05$ - significant statistically difference compared to virgin and pregnant groups (Tukey's Multiple Comparison Test). 
Vi, então, um novo céu e uma nova terra! "Eis aqui o tabernáculo de Deus com os homens. Habitará com eles e serão seu povo, e Deus mesmo estará com eles. Enxugará toda lágrima de seus olhos e já não haverá morte, nem luto, nem grito, nem dor, porque passou a primeira condição". "Eis que faço nova todas as coisas."

Apocalipse 21:1

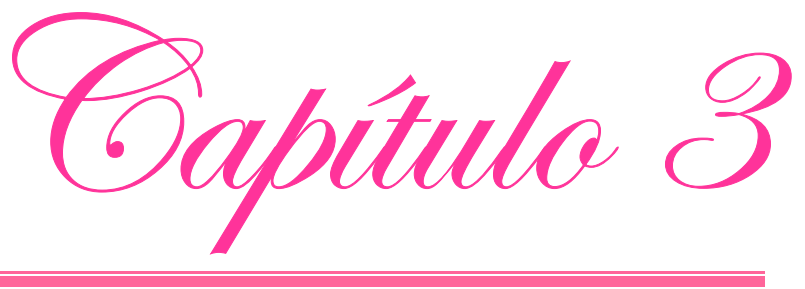




\section{Alterações morfológicas das fibras tipos I e II do músculo estriado uretral de ratas prenhes diabéticas}

Autora: Gabriela Marini

Orientadora: Marilza Vieira Cunha Rudge

Co-orientadoras: Angélica Mércia Pascon Barbosa, Selma Maria Michelin Matheus

Banca: Marilza Vieira Cunha Rudge, Débora Cristina Damasceno, Manoel João Batista Castello Girão

Data da apresentação: 25 de fevereiro de 2010 


\section{RESUMO}

Objetivos: avaliar as alterações morfológicas das fibras musculares estriadas tipos I e || da uretra de ratas prenhes diabéticas submetidas à cesárea. Métodos: Foram avaliadas 20 ratas Wistar distribuídas em quatro grupos: virgem, prenhe, diabético virgem e prenhe diabético. Os três primeiros grupos foram estudados para servir como controle do grupo principal, o prenhe diabético. O diabete foi induzido com streptozotocin na dose de $40 \mathrm{mg} / \mathrm{kg}$ de peso corpóreo. O critério de inclusão foi uma glicemia acima de $200 \mathrm{mg} / \mathrm{dL}$. No final do experimento, as ratas foram anestesiadas e eutanasiadas para realização da laparotomia exploratória. A vagina e a uretra foram retiradas em monobloco, congeladas em nitrogênio líquido e mantidas a $-80^{\circ} \mathrm{C}$. $\mathrm{O}$ bloco foi submetido a cortes em criostato (6 $\mu \mathrm{m}$ de espessura). As lâminas foram coradas por H\&E e utilizados anticorpos anti-miosina lenta e rápida para tipagem das fibras. Foi realizada análise morfológica e semi-quantitativa dos quatro grupos. Resultados: O músculo estriado uretral do grupo prenhe diabético apresentou: adelgaçamento, atrofia, desorganização e rompimento associado à perda de localização anatômica normal das fibras rápidas e lentas e diminuição na proporção de fibras rápidas. Conclusões: Este estudo sugere que o binômio diabete e prenhez danificou o músculo estriado uretral e alterou a composição e a distribuição das fibras tipo I e II .

Palavras-chave: diabete, fibra muscular estriada, prenhez, uretra 


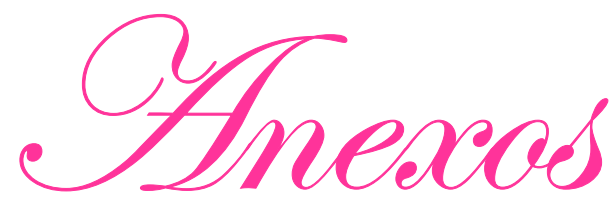




\section{ANEXO 1 - Aprovação do Comitê de Ética}

\section{unesp

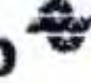

\section{Universidade Estadual Paulista} Faculdade de Medicina de Botucatu

Distrito Rubiâno Junior, s/nn - Botucatu - S.P.

CEP $18.618-970$

FonerFax (Oox14) 3811-6143

e-mad secretaria capellup(B) imb. unesp. br

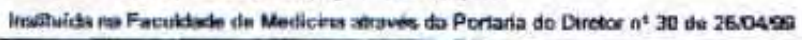

Botucatu, 28 de maio de 2.009

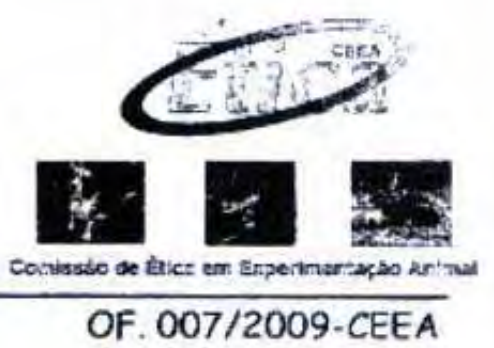

OF. 007/2009-CEEA

Ilustríssima Senhora

Prof ${ }^{\circ} \mathrm{Dr}^{a}$ Marilza Vieira Cunha Rudge

Departamento de Ginecologia e Obstetrícia da

Faculdade de Medicina de Botucatu.

Cara Dr ${ }^{\circ}$ Marilza,

Em atenção à sua solicitação contida no ofício datado de 08 de maio de 2.009 . informo que em reunião da CEEA de 28 de maio de 2.009, foi autorizada a inclusão dos sub-grupos "estudo de ratas nulíparas diabéticas e prenhes diabéticas", referentes ao Protocolo 668-2009, aprovado por esta Comissão em 27/03/2008.

Com a inclusão dos "sub-grupos", o Protocolo 668-2009, teve seu título alterado na seguinte conformidade:

Título anterior: "Estudo morfológico da musculatura vaginal e uretral em ratas prenhes: montagem de modelo experimental" - autoria de Gabriela Marini, orientada pela Prof ${ }^{a} \mathrm{Dr}^{\circ}$ Marilza Vieira Cunha Rudge.

Título atual: "Estudo morfológico da musculatura vaginal e uretral em ratas prenhes diabéticas: montagem de um modelo experimental" - autoria de Gabriela Marini, orientada pela Prof ${ }^{a} \mathrm{Dr}^{a}$ Marilza Vieira Cunha Rudge.

\section{Atenciosamente,}

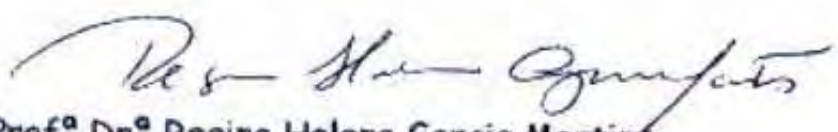

Prof ${ }^{a} D r^{\circ}$ Regina Helena Garcia Martins

Presidente da CEEA. 


\section{ANEXO 2 - Alteração no título}

unesp

OMLSÄO TECNGCA ACADEMICA
UNIVERSIDADE ESTADUAL PAULISTA

CÂMPUS DE BOTUCATU

FACULDADE DE MEDICINA

Seșâo de Pöa-Gradeaç̣âa
Fis

Proc.

Rub.

BOTUCATU, SP - RUBIĀO JÚNIOR - CEP 18618-970 - PABX (0xx14) 3811-6022

\section{JUSTIFICATIVA DE ALTERAÇÃO NO TITULO DO PROJETO DE PESQUISA}

Declaramos que o Projeto de Pesquisa "Estudo morfológico da musculatura vaginal e uretral em ratas prenhes diabéticas: montagem de um modelo experimental" aprovado pelo CEP em 27/ 03/2008, teve seu título alterado para "Alteraçōes morfológicas das fibras tipos I e II do músculo estriado uretral de ratas prenhes diabéticas", sem nenhuma alteração no seu conteúdo metodológico da época de apresentaçăo para análise do CEP.

A presente alteraçấo foi efetuada somente para adequação do título da Dissertação de Mestrado.

Botucatu, 27 de janeiro de 2010

Nome/Assinatura da aluna Gabriela Marini

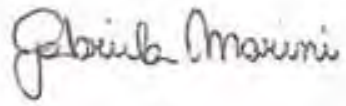

Nome/Assinatura da orientadora Marilza Vieira Cunha Rudge

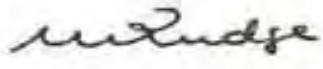

Programa de Pós Graduação em Ginecologia e Obstetricia

- Preencher formulário em 2 vias e protocolar no respectivo CEP 


\section{ANEXO 3 - Ofício do envio para publicação do Capítulo 1}

\section{DIABETOLOGY \&}

METABOLIC SYNDROME

\section{Article title: Diabetes in pregnancy and urinary incontinence: a little acknowledged association}

MS ID : : 1906283565344512

Authors : Gabriela Marini, Angelica MP Barbosa, Débora C Damasceno, Rodrigo A Castro, Selma MM Matheus and Marilza VC Rudge

Journal : Diabetology \& Metabolic Syndrome

Dear Dr Marini

Thank you for submitting your article. This acknowledgement and any queries below are for the contact author. This e-mail has also been copied to each author on the paper, as well as the person submitting. Please bear in mind that all queries regarding the paper should be made through the contact author.

Regards

The Diabetology \& Metabolic Syndrome Editorial Team

e-mail: editorial@dmsjournal.com

Web: http://www.dmsjournal.com/

Terça-feira, 12 de Janeiro de 2010 12:55 